\title{
EVALUATION OF THE PHYSICAL AND MECHANICAL PROPERTIES OF PARTICLEBOARD MADE FROM GIANT REED (ARUNDO DONAX L.)
}

Teresa García-Ortuño, Javier Andréu-Rodríguez, María T. Ferrández-García, Manuel Ferrández-Villena, and Clara. E. Ferrández-García *

Single-layer experimental particleboards were made from various sizes of Arundo donax particles bonded with urea formaldehyde resin. The experimental panels were tested for their mechanical strength including modulus of rupture (MOR), modulus of elasticity (MOE), internal bonding (IB), screw holding strength (SH), and physical properties (density, moisture content, thickness swelling (TS), and water absorption (WA)) according to the procedures defined by European Union (EN) Standards. The overall results showed that most panels exceeded the EN Standards for MOE, MOR, and IB. The mechanical properties of the particleboard were enhanced as the density increased. Particle size was found to have a profound effect on the board properties.

Keywords: Giant reed; Arundo donax L; Particleboard; Particle size; Mechanical properties

Contact information: Department of Engineering, Escuela Politécnica Superior de Orihuela, Universidad Miguel Hernández de Elche, Spain. *Corresponding author: cferrandez@umh.es

\section{INTRODUCTION}

Particleboard is a wood-based panel product manufactured under pressure and temperature from particles of wood or other lignocellulosic fibrous materials and a binder. It is used widely in the manufacture of furniture, floor underlayment, and interior decoration (wall and ceiling panelling) (Anonymous 1996). The primary lignocellulosic materials used in the particleboard industry are woods, but non-woods plant fibers and agro-based residues have also been investigated for producing particleboard. The use of agricultural residues as a raw material in the forest industry dates back to 1900s for pulp and panel industry (Çopur et al. 2007). The literature review by Youngquist and coworkers (1994) cited 1165 research reports worldwide on use of non-wood plant fibers for building materials and panels from 1913 to 1993. In the last decade, research has been carried out on a wide variety of annual plants and agricultural residues such as: wheat straw (Han et al. 1998; Mo et al. 2003 ), rice husk (Ciannamea et al. 2010), cotton carpel (Alma et al. 2005), cotton stalks (Guler and Ozen 2004), peanut shell flour (Batalla et al. 2005), peanut hull (Guler et al. 2008), almond shell (Gürü et al. 2006), flax shiv (Papadopoulos and Hague 2003), sunflower stalks (Guler et al. 2006; Khristova et al. 1998), eggplant stalks (Guntekin and Karakus 2008), date palm (Nemli et al. 2001), vine prunings (Ntalos and Grigoriou 2002), kenaf (Grigoriou et al. 2000), hazelnut husk (Çöpur et al., 2008), bamboo chips (Papadopoulos et al, 2004), and sugar cane bagassebamboo (Lee et al. 2005). 
In the last decade, European agricultural research has focused much attention on the search for new, non-food crops with regard to their industrial utilisation. The grass Arundo donax L. (giant reed) (Poacea) has been considered as one of the more-promising crops (EC FAIR-CT96-2028 Project, 2001) (Shatalov and Pereira 2005). Giant reed is a perennial, herbaceous species growing in grasslands and wetlands, and is an invasive, riparian plant and potential bioenergy crop (Lewandowski et al. 2003; Graziani and Steinmaus 2009). Giant reed is thought to have originated from Asia, but it is also considered as a native species in the countries surrounding the Mediterranean Sea. From this area, it has become widely dispersed by man into all of the subtropical and warmtemperate areas of the world because of its multiple uses (Lewandowski et al. 2003). In the Southeast of Spain, giant reed was used as a building material (walls, frameworks, roofs, fences) for livestock and housing and for erosion control until the beginning of the $20^{\text {th }}$ century. Giant reed has invaded the River Segura Basin (Southern Spain), consuming water from this river that is needed for agricultural use. Large clumps alter stream flow patterns, increase flood damage (Frandsen and Jackson, 1994; Moran and Goolsby 2009), and displace populations of native plants and animals (Bell 1997; Herrera and Dudley 2003). Physical (burning), mechanical (mowing or mulching), and chemical control (Tracy and DeLoach 1999) are the methods commonly used to solve these problems, but they do not have sufficient impact. In this research giant reed culms were used to manufacture particleboard panels in order to give added value to the residue.

Many reports appear in the literature on studies concerned with the effect of particle geometry and alignment on the resultant particleboard strength properties (Kelly 1977). Lee et al. (2006) investigated the influence of fiber morphology, slenderness ratios, and fiber mixing combinations on the mechanical and physical properties of agrobased MDF. They concluded that the material geometry and fiber refinement influenced the mechanical properties of agro-based MDF. Pan et al. (2007) studied the effect of the particle size on the physical and mechanical properties of particleboard made from saline eucalyptus. They found differences in the properties of the resultant particleboards; those that had been manufactured with the medium-sized particles had better qualities.

To the best of our knowledge there have been no other studies to investigate the feasibility of manufacturing particleboards from giant reed. Therefore, the objectives of this study are to use particles from giant reed culms, of different sizes, as a raw material for laboratory-made particleboard panels and to test the properties of such boards to determine if they are comparable to particleboards made from other species.

\section{EXPERIMENTAL}

\section{Materials}

Giant reed culms (Arundo donax L.), were purchased from a commercial factory in Alicante (Spain) and were dried for 6 months under ambient conditions, to 8.6\% moisture content, before use. The average culm height and diameter were $5.5 \mathrm{~m}$ and 2 $\mathrm{cm}$, respectively. After removing any remains of plumes and leaves, the culms were manually cut into slices (ca. 40cm long) and chipped in a laboratory-scale ring-knife chipper, equipped with a screen having $10-\mathrm{mm}$ openings. The particles were then 
classified, using a horizontal screen shaker with sieves of 8-4-2-1-0.25 mm to remove oversize and undersize (dust) particles. A combination of the fractions retained on each sieve was used for the panel manufacture (Table 1). A sample of the different sizes of the particles can be seen in Fig. 1.

Table 1. Combination of Particles used for Particleboard Manufacture

\begin{tabular}{|c|c|c|c|c|}
\hline \multirow{2}{*}{ Board Type } & \multicolumn{4}{|c|}{ Fractions retained on the sieves } \\
\cline { 2 - 5 } & $0.25 \mathrm{~mm}$ & $1.00 \mathrm{~mm}$ & $2.00 \mathrm{~mm}$ & $4.00 \mathrm{~mm}$ \\
\hline A & $50.0 \%$ & $50.0 \%$ & & \\
\hline B & $33.3 \%$ & $33.3 \%$ & $33.3 \%$ & \\
\hline C & & $50.0 \%$ & $50.0 \%$ & $33.3 \%$ \\
\hline D & & $33.3 \%$ & $33.3 \%$ & $50.0 \%$ \\
\hline E & & & $50.0 \%$ & \\
\hline
\end{tabular}

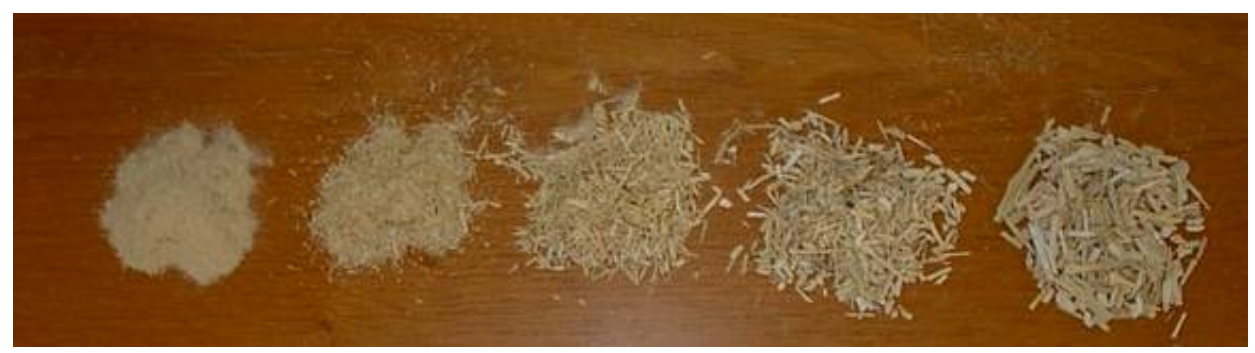

Fig 1. Giant reed particles (from left to right fractions retained on the following sieves $0.25,1,2$, 4 , and $8 \mathrm{~mm}$ ).

Particles were blended with urea formaldehyde (UF) resin with a solid content of 64 to $66 \%$, at the level of $8 \%$, based on the weight of particles ( $8.6 \%$ moisture content). As a hardener, $0.4 \%$ of ammonium sulphate, based on the weight of particles $(8.6 \%$ moisture content), was used. Some chemical and anatomical characteristics of giant reed are shown in Table2.

\section{Methods}

Five types of panel were made. Pre-weighed raw material was placed into a laboratory drum glue blender (Model LGB 100; IMAL S.r.l., Modena, Italy). Before spraying the resin, the hardener was dissolved at a 4\% concentration in water and immediately mixed with the adhesive. The glue mixture was then sprayed onto the particles with pneumatic nozzles and blended for $5 \mathrm{~min}$ at ambient temperature to obtain a homogenized mixture. No wax or other hydrophobic substances were used. The mat configuration was single layer. Boards measuring $50 \mathrm{~cm}$ x $35 \mathrm{~cm}$ were manually formed and pressed in a hot press at $3.5 \mathrm{~N} / \mathrm{mm}^{2}$, at $120^{\circ} \mathrm{C}$, for $6 \mathrm{~min}$. The experimental design is shown in Table 3. 
Table 2. Chemical and Anatomical Characteristics of Arundo donax Stems

\begin{tabular}{|c|c|c|c|c|c|c|c|}
\hline \multirow[t]{2}{*}{ Component } & \multicolumn{2}{|c|}{$\begin{array}{l}\text { Shatalov et al. } \\
(2001)\end{array}$} & \multicolumn{2}{|c|}{$\begin{array}{l}\text { Ververis et al. } \\
(2004)\end{array}$} & \multicolumn{2}{|c|}{$\begin{array}{l}\text { Pascoal Neto et } \\
\text { al. (1997) }\end{array}$} & \multirow{2}{*}{$\begin{array}{c}\text { Caparrós } \\
\text { et al. } \\
\text { (2006) }\end{array}$} \\
\hline & Node & $\begin{array}{l}\text { Interno- } \\
\text { de }\end{array}$ & Node & $\begin{array}{c}\text { Interno- } \\
\text { de }\end{array}$ & Node & $\begin{array}{c}\text { Interno- } \\
\text { de }\end{array}$ & \\
\hline Ash (\% o.d. reed) & 4.77 & 6.14 & 5.33 & 4.53 & 3.03 & 3.80 & 3.00 \\
\hline Silicates & 1.31 & 1.16 & & & & & \\
\hline $\begin{array}{l}\text { Extractives (\% o.d. } \\
\text { reed) }\end{array}$ & 13.04 & 11.16 & & & 18.07 & 18.30 & \\
\hline Dichloromethane & 0.46 & 0.37 & & & & & \\
\hline Ethanol & 5.88 & 4.18 & & & & & 9.10 \\
\hline Hot water & 6.70 & 6.61 & & & & & \\
\hline Lignin (\% o.d. reed) & 20.92 & 21.31 & & & 17.70 & 19.40 & 23.00 \\
\hline Klason & 19.03 & 19.60 & 18.30 & 18.33 & & & \\
\hline Acid-soluble & 1.89 & 1.71 & & & & & \\
\hline Holocellulose & 61.21 & 61.41 & & & 57.70 & 62.17 & 64.50 \\
\hline a-Cellulose & 29.18 & 32.93 & 32.43 & 36.27 & 30.80 & 34.63 & 34.80 \\
\hline Hemicelluloses & 32.03 & 28.48 & & & & & \\
\hline Parenchyma (\%) & 55.80 & 59.80 & & & & & \\
\hline Fibre (\%) & 37.90 & 33.90 & & & & & \\
\hline Vascular tissue (\%) & 6.40 & 6.20 & & & & & \\
\hline Fibre length (mm) & 1.20 & 1.20 & 1.18 & 1.22 & & & \\
\hline Fibre width $(\mu \mathrm{m})$ & 16.90 & 14.60 & & & & & \\
\hline $\begin{array}{l}\text { Fibre wall thickness } \\
(\mu \mathrm{m})\end{array}$ & 5.30 & 4.60 & 5.60 & 4.40 & & & \\
\hline Fibre diameter $(\mu \mathrm{m})$ & & & 18.80 & 17.30 & & & \\
\hline Lumen diameter $(\mu \mathrm{m})$ & & & 8.60 & 8.50 & & & \\
\hline
\end{tabular}

Table 3. Production Parameters of Single-Layer Particleboards

\begin{tabular}{lc}
\hline \multicolumn{1}{c}{ Parameter } & Value \\
\hline Press temperature $\left({ }^{\circ} \mathrm{C}\right)$ & 120 \\
Pressing time $(\mathrm{min})$ & 6 \\
Press pressure $\left(\mathrm{N} / \mathrm{mm}^{2}\right)$ & 3.5 \\
Dimensions $(\mathrm{mm})$ & $500 \times 350$ \\
Thickness $(\mathrm{mm})$ & $7.25-10.61$ \\
Number of boards of each type & 2 \\
\hline
\end{tabular}

Two replicate panels were made for each board type. After pressing, the particleboards were conditioned at $20{ }^{\circ} \mathrm{C}$ and $65 \%$ relative humidity for four weeks in a vertical position (Fig. 2). The finished particleboards were trimmed to avoid edge effects to a final size of $50 \mathrm{~cm} \times 35 \mathrm{~cm}$, and then cut into various sizes for property evaluation according to EN 326-1 (1999) (Fig. 3). 

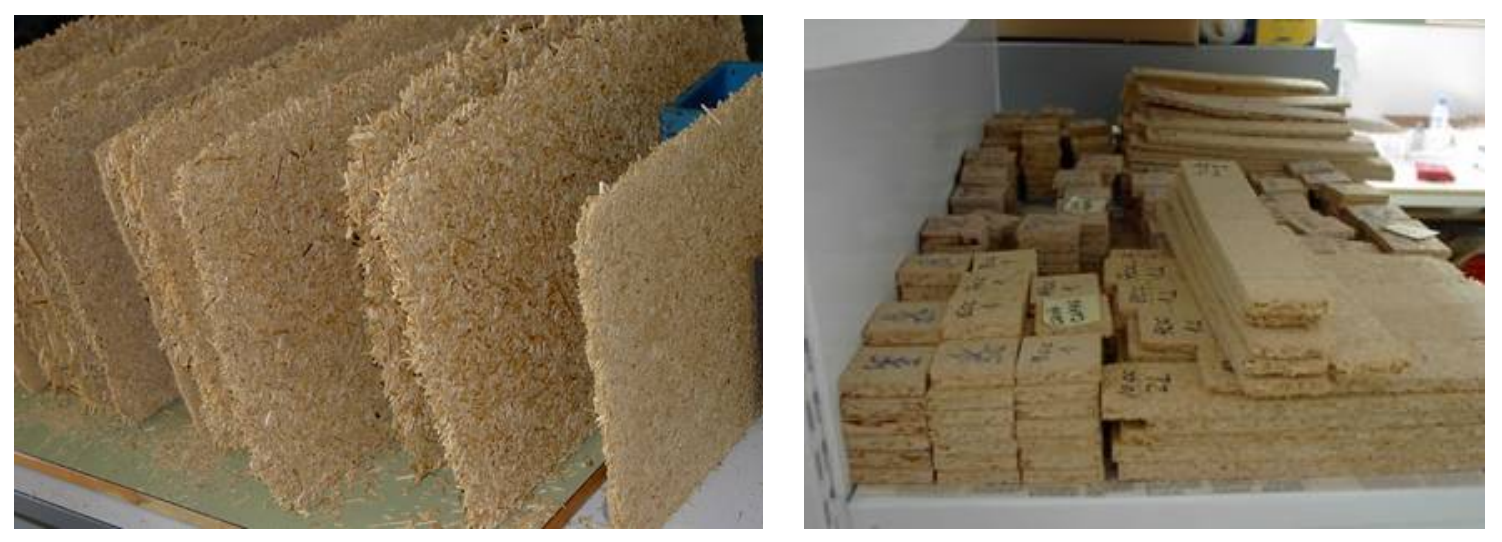

Fig 2. (left) Finished particleboards during conditioning at $20^{\circ} \mathrm{C}$ and $65 \%$ relative humidity;

Fig 3. (right) Particleboard samples stored after the assessment

Some physical properties were determined in accordance with appropriate EN standards: moisture content (MC) (EN 322, 1993), density (EN 323, 1993), water absorption (WA), and thickness swelling (TS) after a 24-hour immersion (EN 317, 1993). The mechanical properties determined were: modulus of rupture (MOR) and modulus of elasticity (MOE) (EN 310, 1993), internal bond strength (IB) (EN 319, 1993), and screw holding strength (SH) (EN 320, 1993). Each panel was cut to get one MC sample (rectangular and $20 \mathrm{~g}$ in weight), six density samples (50 $\mathrm{mm} \times 50 \mathrm{~mm}$ ), three WA/TS samples (70 mm x $70 \mathrm{~mm}$ ), six MOR/MOE samples (different lengths, depending on the thickness, x $50 \mathrm{~mm}$ width), three IB samples (50 mm x $50 \mathrm{~mm}$ ), and three SH samples (50 mm x $50 \mathrm{~mm}$ ).

Tests for mechanical properties, WA, TS, and density were conducted on an Imal universal testing machine (Model IB600, Modena, Italy).

Data for each test were analysed statistically. Analysis of variance (ANOVA) and $t$-test calculations were used to test $(\alpha=0.05)$ for significant difference between factors and levels. When the ANOVA indicated a significant difference among factors and levels, a comparison of the means was performed, employing Duncan's test to identify which groups were significantly different at the $95 \%$ confidence level.

\section{RESULTS AND DISCUSSION}

\section{Physical Properties}

The density ranged from 628.33 to $758.11 \mathrm{~kg} / \mathrm{m}^{3}$. The thickness of the produced particleboards ranged 7.25 to $10.61 \mathrm{~mm}$. And the moisture content ranged from 6.25 to $10.61 \%$. Water absorption and thickness swelling test results are shown in Table 4. Particleboards should have a maximum thickness swelling value of $16 \%$ for 24 -h immersions, for load bearing (EN 312, 2003). Average thickness swelling of the specimens following a 24-h immersion ranged from $15.04 \%$ to $35.9 \%$. Panels C and D were found to comply with thickness swelling values for load bearing and had the highest densities. The TS values increased with decreasing the board density, except for panel E. 
Table 4. Mean Values of Physical Properties of Particleboards

\begin{tabular}{cccccc}
\hline Type & $\mathrm{D}\left(\mathrm{kg} / \mathrm{m}^{3}\right)$ & $\mathrm{MC}(\%)$ & Thickness $(\mathrm{mm})$ & $\mathrm{TS}(\%) 24 \mathrm{~h}$ & WA (\%) 24 h \\
\hline A & $687.43(30.22) \mathrm{b}$ & 7.01 & $9.87(0.40)$ & $27.85(4.69) \mathrm{b}$ & $67.79(5.56) \mathrm{b}$ \\
B & $682.79(89.38) \mathrm{b}$ & 6.25 & $7.25(1.78)$ & $35.91(5.06) \mathrm{a}$ & $79.23(8.19) \mathrm{a}$ \\
C & $738.52(16.95) \mathrm{a}$ & 7.09 & $8,85(0.33)$ & $15.04(0.54) \mathrm{c}$ & $42.82(3.58) \mathrm{d}$ \\
D & $758.11(17.93) \mathrm{a}$ & 7.06 & $8.50(0,58)$ & $15.95(1.36) \mathrm{c}$ & $42.31(0.91) \mathrm{d}$ \\
E & $628.33(45.56) \mathrm{c}$ & 7.45 & $10.61(1.16)$ & $28.71(4.56) \mathrm{b}$ & $61.23(3.73) \mathrm{c}$
\end{tabular}

Requirements $^{\mathrm{A}}$

16.00

Values with the same letter in the same column are not significantly different based on Duncan's multiple-range test at the 0.05 significance level.

Values in parentheses are standard deviations.

A Maximum requirement for load bearing under dry conditions, according to EN 312 (2003) standard.

Panel E had the lowest density, the highest thickness, and was manufactured with the biggest particle size. These properties may be attributable to an insufficient application of pressure during the compression of the mat. Kelly (1977) reported that a higher pressure was required to reach a desired specific gravity for narrower and thicker flakes as opposed to wider and thinner flakes.

\section{Mechanical Properties}

The average values of modulus of rupture, modulus of elasticity, internal bond, and screw-holding strength are given in Table 5.

Table 5. Mean Values of Mechanical Properties of Particleboards

\begin{tabular}{crccr}
\hline Type & MOR $\left(\mathrm{N} / \mathrm{mm}^{2}\right)$ & $\operatorname{MOE}\left(\mathrm{N} / \mathrm{mm}^{2}\right)$ & \multicolumn{1}{c}{$\mathrm{IB}\left(\mathrm{N} / \mathrm{mm}^{2}\right)$} & \multicolumn{1}{c}{$\mathrm{SH}(\mathrm{N} / \mathrm{mm})$} \\
\hline A & $13.67(1.66) \mathrm{b}$ & $2394.74(495.74) \mathrm{b}$ & $0.258(0.177) \mathrm{d}$ & $42.19(10.59) \mathrm{d}$ \\
B & $13.67(1.61) \mathrm{b}$ & $2812.08(360.35) \mathrm{a}$ & $0.350(0.155) \mathrm{cd}$ & $41.69(25.21) \mathrm{d}$ \\
C & $17.67(2.10) \mathrm{a}$ & $3025.90(290.92) \mathrm{a}$ & $1.026(0.232) \mathrm{b}$ & $95.37(4.54) \mathrm{b}$ \\
D & $17.10(1.36) \mathrm{a}$ & $2997.51(357.60) \mathrm{a}$ & $1.309(0.148) \mathrm{a}$ & $120.43(6.63) \mathrm{a}$ \\
E & $9.93(2.93) \mathrm{c}$ & $1467.86(50.19) \mathrm{c}$ & $0.543(0.079) \mathrm{c}$ & $63.21(9.05) \mathrm{c}$
\end{tabular}

\begin{tabular}{|c|c|c|c|c|}
\hline Requirements ${ }^{A}$ & 12.5 & $\mathrm{~N} / \mathrm{A}$ & 0.28 & N/A \\
\hline Requirements $^{B}$ & 13.0 & 1800.00 & 0.40 & $\mathrm{~N} / \mathrm{A}$ \\
\hline Requirements $^{\mathrm{C}}$ & 15.0 & 2300.00 & 0.45 & $\mathrm{~N} / \mathrm{A}$ \\
\hline $\begin{array}{l}\text { Values with the s } \\
\text { multiple-range te } \\
\text { Values in parenth } \\
\text { A For general use } \\
\text { B For interior gra } \\
\text { C F }\end{array}$ & $\begin{array}{l}\text { gnifica } \\
\text { ard de } \\
\text { EN } 31\end{array}$ & re not sigr & rent ba & \\
\hline
\end{tabular}


Based on EN standards, $12.5 \mathrm{~N} / \mathrm{mm}^{2}$ and $13 \mathrm{~N} / \mathrm{mm}^{2}$ are the minimum requirements for MOR of particleboards for general uses and furniture manufacturing, respectively (EN 312, 2003). There is no minimum requirement for $\mathrm{MOE}$ for general uses, and for furniture manufacturing the value is $1800 \mathrm{~N} / \mathrm{mm}^{2}$ (EN 312, 2003). The values of MOR ranged from 9.93 to $17.67 \mathrm{~N} / \mathrm{mm}^{2}$. The values of MOE lay between 1467.86 and $3025.90 \mathrm{~N} / \mathrm{mm}^{2}$. Particleboards made from smaller particles (types A and B) had MOR and MOE values that are sufficiently high to meet the requirements for general uses and furniture manufacturing. Panels $C$ and $D$ exceeded the requirements for load bearing, while panel type E had lower MOR and MOE values than those specified. Panels having the greatest densities had the greatest values of MOR and MOE, suggesting that the particleboard density plays a very-important role on the bending strength, as expected.

The IB strength values obtained ranged from 0.258 to $1.309 \mathrm{~N} / \mathrm{mm}^{2}$. Particleboards types $\mathrm{C}, \mathrm{D}$, and $\mathrm{E}$ had IB values that met the requirements for load bearing. Panel type B achieved the level of internal bond required for general purposes, while type A had the worst IB value. This indicates that the IB strength increases with increasing particle size.

\section{CONCLUSIONS}

The results presented here suggest that it is completely feasible to manufacture acceptable or high-quality particleboard using giant reed as an alternative lignocellulosic raw material. Since particleboards produced with particles of sizes from 1 to $2 \mathrm{~mm}$ and 1 to $4 \mathrm{~mm}$ had the most desirable quality, the production of such sizes is recommended for the milling of the culms.

Particle size was found to have a great effect on the properties of UF-bonded giant reed particleboards manufactured from particles of five different sizes.

Since boards are considered high-value, long-life products - they have life expectancies of several decades - productive giant reed systems could be considered a carbon sink. The use of renewable materials such as giant reed for manufacturing particleboards could help to alleviate the scarcity of raw material for the particleboard industry.

\section{ACKNOWLEDGMENTS}

The authors wish to acknowledge Dr. David J. Walker for his revision of the written English. This work has been financed by the Ministerio de Ciencia e Innovación of Spain (MICCIN, BIA 2009-11605). 


\section{REFERENCES CITED}

Alma, M. H., Kalaycioglu, H., Bektas, A., and Tutus, A. (2005). "Properties of cotton carpel-based particleboards," Ind. Crops Prod. 22, 141-149.

Anonymous (1996). Particleboard - From Start to Finish, National Particleboard Association. Gaithersburg. Maryland. USA

Batalla, L., Nuñez, A. J., and Marcovich, N. E. (2005). "Particleboards from peanut-shell flour,” J. Appl. Polym. Sci. 97, 916-923.

Bell, G. P. (1997). "Ecology and management of Arundo donax, and approaches to riparian habitat restoration in Southern California,” In: Brock, J. H., Wade, M., Pysek P., and Green D. (eds.), Plant Invasions: Studies from North America and Europe, Blackhuys Publishers, Leiden, The Netherlands, 103-113.

Caparrós, S., Ariza, J., Hernanz, D., and Díaz, M .J. (2006). “Arundo donax L. valorization under hydrotermal and pulp processing,” Ind. Eng. Chem. Res. 45, 29402948.

Ciannamea, E. M., Stefani, P. M, and Ruseckaite, R. A. (2010). "Medium-density particleboards from modified rice husks and soybean protein concentrate-based adhesives,” Biores. Technol. 101, 818-825.

Çöpur, Y., Guler, C., Tasçioglu, C., and Tozluoglu, A. (2008). "Incorporation of hazelnut shell and husk in MDF production,” Bioresour. Technol. 99, 7402-7406.

Çöpur, Y., Guler, C., Akgül, M., and Tasçioglu, C., (2007). "Some chemical properties of hazelnut husk and its suitability for particleboard production,” Build. Environ. 42 2568-2572.

EN 310 (1993). "Wood-based panels. Determination of modulus of elasticity in bending and of bending strength."

EN 312 (2003). "Particleboards. Specifications."

EN 317 (1993). "Particleboards and fibreboards. Determination of swelling in thickness after immersion in water."

EN 319 (1993). "Particleboards and fibreboards. Determination of tensile strength perpendicular to the plane of the board."

EN 320 (1993). "Fibreboards. Determination of resistance to axial withdrawal of screws."

EN 322 (1993). "Wood-based panels. Determination of moisture content.”

EN 323 (1993). "Wood-based panels. Determination of density."

EN 326-1(1994). "Wood-based panels. Sampling and cutting of test pieces and expression of test results."

Frandsen, P., and Jackson, N. (1994). "The impact of Arundo donax on flood control and endangered species,” In: Jackson, N. E., Frandsen, P., and Duthoit, S. (Compilers), Arundo donax Workshop Proceedings, 19 November 1993, Ontario, California, USA. Team Arundo and California Exotic Pest Plant Council, Pismo Beach, CA, pp. 13-16.

Graziani, A., and Steinmaus, S. J. (2009). "Hydrothermal and thermal time models for the invasive grass, Arundo donax,” Aquatic Botany 90, 78-84.

Grigoriou, A., Passialis, C., and Voulgaridis, E. (2000). "Experimental particleboards from kenaf plantations grown in Greece,” Holz als Roh - und Werkstoff 58, 309-314.

Guler, C., and Ozen, R. (2004). "Some properties of particleboards made from cotton stalks (Gossypium hirsutum L.),” Holz als Roh- und Werkstoff 62, 40-43. 
Guler, C., Bektas, I., and Kalaycioglu, H. (2006). “The experimental particleboard manufacture from sunflower stalks (Helianthus annuus L.) and calabrian pine (Pinus brutia ten.)," Forest Prod. J. 56(4), 56-60.

Guler, C., Copur, Y., and Tascioglu, C. (2008). “The manufacture of particleboards using mixture of peanut hull (Arachis hypogaea L.) and European Black pine (Pinus nigra Arnold) wood chips,” Biores. Technol. 99, 2893-2897.

Guntekin, E., and Karakus, B. (2008). "Feasibility of using eggplant (Solanum melongena) stalks in the production of experimental particleboard.” Ind. Crops Prod. 27(3), 354-358.

Gürü, M., Tekeli, S., and Bilici, I. (2006). "Manufacturing of urea-formaldehyde-based composite particleboard from almond shell,” Mater. Des. 27, 1148-1151.

Han, G., Zhang, C., Zang, D., Umemura, K., and Hawai, S. (1998). “Upgrading of urea formaldehyde-bonded reed and wheat straw particleboards using silane coupling agents,” J. Wood Sci. 44, 282-286.

Herrera, A. M., and Dudley, T. L. (2003). "Reduction of riparian arthropod abundance and diversity as a consequence of giant reed (Arundo donax) invasion," Biological Invasions 5, 167-177.

Kelly, M. W. (1977). “Critical literature review of relationships between processing parameters and physical properties of particleboard,” Gen. Tech. Rept. FPL-10. USDA Forest Serv., Forest Prod. Lab., Madison, Wisconsin. USA

Khristova, P., Yossifov, N., Gabir, S., Glavche, I., and Osman, Z. (1998). "Particleboards from sun flower stalks and tannin-modified UF resin,” Cellul. Chem. Technol. 32, 327-337.

Lee, S., Shupe, T. F., and Hse, C. Y. (2006). "Mechanical and physical properties of agro-based fibreboard," Holz als Roh- und Werkstoff 64, 74-79.

Lewandowski, I., Scurlock, J. M. O., Lindvall, E., and Christou, M. (2003). “The development and current status of perennial rhizomatous grasses as energy crops in the US and Europe,” Biomass Bioenerg. 25, 335-361.

Mo, X., Cheng, E., Wang, D., and Sun, X. S. (2003). "Physical properties of medium density wheat straw particleboard using different adhesives," Ind. Crops Prod. 18, 47-53.

Moran, P. J., and Goolsby, J. A. (2009). "Biology of the galling wasp Tetramesa romana, a biological control agent of giant reed,” Biological Control 49 (2), 169-179.

Nemli, G., Kalaycioglu, H., and Alp, T. (2001). "Suitability of date palm branches for particleboard production,” Holz als Roh- und Werkstoff 59, 411-412.

Ntalos, G. A., and Grigoriou, A. H. (2002). "Characterization and utilisation of vine prunings as a substitute for particleboard production,” Ind. Crops Prod. 16, 59-68.

Pan, Z., Zheng, Y. Zhang, R., and Jenkins, B. M., (2007).” Physical properties of thin particleboard made from saline eucalyptus,” Ind. Crops Prod. 26, 185-194.

Papadopoulos, A. N., and Hague, J. R. B., (2003). "The potential use of Linum usitatissimun (flax) chips as a raw lignocellulosic material for particleboards,” Ind. Crops Prod. 17(2), 143-147.

Papadopoulos, A. N., Hill, C. A. S., Gkaraveli, A., Ntalos, G. A., and Karastergiou, S. P. (2004). "Bamboo chips (Bambusa vulgaris) as an alternative lignocellulosic raw material for particleboard manufacture,” Holz als Roh - und Werkstoff 62, 36-39. 
Pascoal Neto, C., Seca, A., Nunes, A. M., Coimbra, M. A., Domínguez, F., Evtuguin, D., Silvestre, A., and Cavaleiro, J. A. S. (1997). "Variations in chemical composition and structure of macromolecular components in different morphological regions and maturity stages of Arundo donax,” Ind. Crops Prod. 6, 51-58.

Shatalov, A. A., Quilho, T., and Pereira, H. (2001) “Arundo donax L. reed: New perspectives for pulping and bleaching -1. Raw material characterization,” TAPPI J. 84(11), 1-12.

Shatalov, A. A., and Pereira, H. (2005). "Kinetics of organosolv delignification of fibre crop Arundo donax L,” Ind. Crops Prod. 21 (2), 203-210.

Tracy, J. L., and DeLoach, C. J. (1999). "Suitability of classical biological control for giant reed (Arundo donax) in the United States," In: Bell C., (ed.), Arundo and Saltcedar Management Workshop Proceedings, 17 June, 1998, Ontario, California. University of California Cooperative Extension, Holtville, California.

Ververis, C., Georghiou, K., Christodoulakis, N., Santas, P., and Santas R. (2004). "Fiber dimensions, lignin and cellulose content of various plant materials and their suitability for paper production,” Ind. Crops Prod. 19, 245-254.

Youngquist, J. A., English, B. E., Scharmer, R. C., Chow, P., and Shook, S. R. (1994). "Literature review on use of nonwood plant fibers for building materials and panels," Gen. Tech. Rept. FPL-GTR-80. USDA Forest Serv., Forest Prod. Lab., Madison, Wisconsin. USA.

Article submitted: October 7, 2010; Peer review completed: November 30, 2010; Revised version received and accepted: December 20, 2010; Published: December 26, 2010. 